Неда Андрић

Универзитет Црне Горе

Филолошки факултет

nedaandric@ucg.ac.me
УДК 821.161.1.09"18"(497.11)

https://doi.org/10.18485/slavistika.2021.25.1.14

Прегледни рад

примљено 28.04.2021.

прихваћено за штампу17.06.2021.

\title{
ТЕАНТРОПОЛОГИЈА ДОСТОЈЕВСКОГ. РЕЦЕПЦИЈА СТВАРАЛАШТВА Ф. М. ДОСТОЈЕВСКОГ У КРИТИЦИ МИТРОПОЛИТА АМФИЛОХИЈА (РАДОВИЋА) И ЕПИСКОПА АТАНАСИЈА (ЈЕВТИЋА)
}

\begin{abstract}
У нашем раду бавићемо се рецепцијом стваралаштва Фјодора Михајловича Достојевског у критици митрополита Амфилохија (Радовића) и епископа (Атанасија) Јевтића кроз призму теантропологије. „Тајна човјека“ и „човјек као тајна“ постају предмет промишљања митрополита Амфилохија и епископа Атанасија јер им се карактер пишчевог дјела открива као антропоцентричан, или, да будемо прецизнији, као теантропоцентричан. Оба аутора у својим радовима запажају да је кључни проблем којим се бави Достојевски у свом књижевном опусу заправо „очовјечење човјека“ и да писац полази од личног искуства приликом откривања различитих димензија човјека. Да би уопште био започет пут очовјечења, неопходно је пронаћи истинског човјека, а ово је могуће једино ако осим вјере у Бога, постоји још и вјера у човјека. Из тога произилази да човјекова мјера једино може бити Богочовјек - Личност која несливено и нераздељиво спаја и повезује двије природе - људску и божанску. Као једина права мјера човјека се тако открива Христос. Митрополит Амфилохије у животном искуству Фјодора Михајловича Достојевског истиче екстатичну љубав према Христу, док епископ Атанасије, између осталог, првенствено наглашава чежњу и стремљење ка Христу.
\end{abstract}

Кључне ријечи: Фјодор Достојевски, теантропологија, човјек, Богочовјек, Христос, митрополит Амфилохије (Радовић), епископ Атанасије (Јевтић).

In our paper, we deal with the reception of the work of Fyodor Dostoevsky by Metropolitan Amfilohije (Radović) and Bishop Atanasije (Jevtić). Although there is a huge amount of studies dedicated to Dostoevsky's work, there are only a few that manage to see the fundamental problems that this writer dealt with in an integrative way. The anthropocentric character of Dostoevsky's work was noticed in the early $20^{\text {th }}$ century by Russian religious thinkers such as Nikolai Berdyaev, Dmitry Merezhkovsky, Vasily Rozanov, and others. «The Secret of Man» and «Man as a Secret» became the subject of reflection of Metropolitan Amfilohije and Bishop Atanasije. Both authors reveal that the key problem in Dostoevsky's literary work is man, more precisely, the «humanization of man» and that the writer starts from his personal experience to discover different dimensions of man. To begin the path of humanization, it is necessary to find the true man, therefore, to believe not only in God but also in man. And the measure of man can only be the God-man - one hypostasis with two natures - human and divine. Christ is thus revealed as the only true measure of man. In the life of Fyodor Dostoevsky, Metropolitan Amfilohije reveals an ecstatic love for Christ, and Bishop Atanasije, among other things, longing and striving for Christ.

Keywords: Fyodor Dostoevsky, theanthropology, man, God-man, Christ, Metropolitan Amfilohije (Radović), Bishop Atanasije (Jevtić).

Николај Берђајев је међу првима примијетио кључну разлику између стваралаштва Достојевског и стваралаштва његових великих претходника из минулих епоха у свјетлу теме којом ћемо се овдје бавити. Човјек Достојевског је у 
потпуности другачији у односу на човјека Дантеовог или у односу на човјека Шекспировог. Код Дантеа „човек је органски део објективног васионског уређења, божанског космоса. Он је члан хијерархијског поретка који је човјеку дат од споља“" (Берђајев 1981: 235). У Шекспировом дјелу се открива душевни свијет човјека: „Дантеовог неба, Дантеовог пакла у Шекспировом стваралаштву нема. Код Шекспира, положај човјека одређује хуманистички поглед на свет“" (Берђајев 1981: 235). Шекспиров човјек осјећа слободу од споља наметнуте хијерархије. За Берђајева је човјек Достојевског човјек једне сасвим друге епохе и другачије схваћене антропологије. То је човјек који израста из подземног свијета и пред нама се отвара подземни свијет у ком је присутна иманентна духовност (а не само душевност): „И тај духовни свет требало је да у почетку остави утисак спуштања у пакао. Тамо ће се човјеку отворити и Бог и небо, а не само Ђаво и пакао, али не као објективни поредак дат човјеку споља, већ као сусрет са свом дубином људског духа, као реалности које се отварају изнутра“" (Берђајев 1981: 236). Ослањајући се добрим дијелом на ово запажање Берђајева, управо од те црте духовне иманентности карактеристичне за човјека Достојевског и креће тумачење са посебним акцентом на антропологију и теантропологију митрополита Амфилохија и епископа Атанасија.

Владимир Николајевич Захаров наглашава једну од основних карактеристика стваралаштва Достојевског: „Достојевски је био један од оних који је у свом стваралаштву органски сјединио религиозно и умјетничко. Већина његових претходника и савременика су живјели у паралелним свјетовима. Богу - Божије, цару - царево“ (Захаров 2005: 15). Са друге стране, Захаров са правом потенцира да „тражити догму у умјетничким дјелима је погрешна замисао са било које тачке гледишта: то једноставно значи не разумијевати природу умјетничког стваралаштва“ (Захаров 2005: 15). Епископ Атанасије (Јевтић) и митрополит Амфилохије (Радовић) указујући на начин осмишљавања и конципирања суштине човјека и хришћанске (трансисторијске) слике свијета у дјелима Достојевског истичу присутност хришћанске традиције и хришћанског кода који доприноси вишеслојности и дубини јунака Достојевског. Бавећи се проблемом теантропологије код Достојевског поменути аутори наглашавају стваралачку суштину хришћанске културне традиције која је присутна у генези сваког великог дјела које припада тој традицији. Митрополит Амфилохије приступа дјелу Фјодора Достојевског на један специфичан начин који не подсјећа на уобичајене поступке већине књижевних критичара: он дјело сагледава цјеловито, онако као што се сагледава „живи живот“. Године 1983, у вријеме одржавања трибине „Достојевски - наш савременик“, митрополит објављује „Пневматолошки метод“ - текст посвећен стваралаштву Достојевског а инспирисан излагањима и дискусијама на овој трибини (Радовић 1983). У то вријеме наши књижевни критичари, као и они са простора совјетске Русије, када се баве анализом појединих романа Достојевског, углавном не узимају у обзир цјелокупан контекст у ком су настали, због чега не успијевају да их у потпуности разумију и сагледају пишчев значај у оквирима свјетске књижевности. Инспирисан начином на који Николај Берђајев приступа ткиву романа Достојевског, митрополит Амфилохије тежи коришћењу пневматолошког метода приликом анализе стваралаштва Фјодора Михајловича Достојевског. Сам 
пневматолошки метод омогућава ономе ко га користи да избјегне учитавање сопственог смисла приликом анализе јер се у духу писца тумачи његово дјело.

Шта значи у том кључу тумачити дјело? Првенствено, бити упознат не само са књижевним опусом, већ и публицистиком, преписком, а кроз њих наслутити духовна трагања, душевне ломове и психичка стања - освијетлити све оно што се може објединити под појмом „чистилиште (огањ) сумње“ (горнило сомнений) да би се на крају дошло до личног сусрета са Богом. Митрополит Амфилохије (Радовић) понавља ријечи свог духовног оца, Јустина Поповића да му је током живота Достојевски у исто вријеме био и ,учитељ и мучитељ“ (мит. Амфилохије 2012: 447). Још од студентских дана овај писац заузима посебно мјесто у његовом сазријевању, а вјероватно, под утицајем свог духовног учитеља и митрополит Амфилохије, као и епископ Атанасије (још један од ученика Јустина Поповића) потпуно су свјесни огромног распона личности Достојевског и многодимензионалности његовог дјела, због чега су се и један и други током цијелог живота бавили темом званом Достојевски.

Генијалност Достојевског као писца огледа се, између осталог, и у способности стварања нових свјетова, чиме се писац приближава свом Творцу. Ти нови, романескни свјетови Достојевског засновани су на отварању могућности перспективе сагледавања човјека у онтолошкој равни. Пошто се у средишту цјелокупне творевине налази човјек, спознаја творевине као тајне најбоље се остварује кроз спознају круне стварања - због чега и основна карактеристика дјела Достојевског јесте антропоцентричност. Човјек Достојевског се разоткрива у својој духовној равни као веза између творевине и Творца, док на душевном плану он остварује релациони однос са другим јунацима романа. Такав човјек, када крене путем самоспознаје, прво у себи, а онда и у свима другима открива боголикост, или прецизније - христоликост. На тај начин се остварује веза уједно и са Другим и са другима.

Још у периоду ране младости Достојевски постаје свјестан колико је за њега тема - човјек значајна. Тако он 1839. године, у познатом писму пише брату Михаилу Михајловичу Достојевском: „Човјек је тајна, ако је будеш одгонетао цијелог свог живота, немој мислити да си живио узалуд. Ја се бавим том тајном јер хоћу да будем човјек“ (Достоевский 1985: 63).

Да стваралаштво Достојевског, првенствено, има филозофско-антрополошки карактер запазили су руски религиозни мислиоци почетком 20. вијека: Владимир Соловјов, Дмитриј Мерешковски, Николај Берђајев, Василиј Розанов, Лав Шестов, Вјачеслав Иванов, Георгије Флоровски. Напоредо и на трагу руске религиозне мисли посебан допринос у освјетљавању „хришћанског кода“ у стваралаштву Достојевског су дали и наши теолози, прије свега, Јустин Поповић, Атанасије Јевтић и Амфилохије Радовић. Да би Достојевски могао уопште сагледавати човјека као највишу тајну омогућава му његов однос, његова љубав према Христу. У писму Фонвизиној из Омска (јануар - фебруар 1854. године), убрзо након изласка из логора (23. јануара) он наводи исповиједање онога у шта вјерује и како вјерује, то јесте, свој символ вјере:

О себи ћу рећи да сам ја дијете вијека, дијете невјеровања и сумње све до овог тренутка, па чак (ја то знам) и до мртвачког сандука. Колико ме 
је само ужасних мука коштала и још кошта толика жеђ за вјеровањем која бива тим јача што је више разлога против. Па ипак, Бог ми понекад шаље тренутке у којима сам потпуно миран; у тим тренуцима ја волим и откривам да ме други воле, и управо у тим тренуцима сам саставио символ вјере у коме ми је све јасно и свето. Тај символ је врло једноставан и ево га: вјеровати да нема ничег љепшег, дубљег, симпатичнијег, разумнијег, храбријег и савршенијег од Христа, и не само да нема, већ и ревњивом љубављу кажем да не може ни бити. Чак и када би ми неко доказао да је Христос ван истине, и када би стварно истина била ван Христа, ја бих радије желио да останем са Христом, него са истином (Достоевский 1985: 176). ${ }^{1}$

Митрополит Амфилохије истиче да Достојевски својом вјером, која јесте примљена свјетлост Христова, осветљава и своје јунаке, без обзира на њихову оријентацију ка добру или злу, без обзира да ли су религиозни, или се крећу другачијим путевима потраге за смислом. И што су више његови јунаци раздвојени између добра и зла они више чезну за цјеловитошћу и пуноћом (савршени лик човјеков у човјеку) која се открива као свечовјечна богочовјечност, Христов Лик. По ријечима самог Достојевског знамо да му је вјера била распета, али и да је спасена: возгласом „осана“ он слободно прихвата Христа као Спаситеља, чиме дозвољава да свјетлост Христовог Лика обасја дубине његове душе. У том духу митрополит Амфилохије новозавјетним стихом свеобухватно сагледава живот и стваралаштво Достојевског. Тај стих је: „И свјетлост свијетли у тами, и тама је не обузе“ (Јн 1,5$)$. У религиозној и духовној проблематици којом се бавио Достојевски у својим дјелима митрополит Амфилохије препознаје и суштинске проблеме савременог човјека. Ова проблематика у нашој култури није била актуелизована у периоду модерне историје, због чега не би требало да чуди судбина религије током друге половине 20. вијека. Међутим, и у 21. вијеку Достојевски не губи на својој актуелности: све значајнија постају питања везана за идентитет човјека, шта то човјека чини човјеком у времену идеја трансхуманизма и постхуманизма.

У умјетничком свијету Достојевског тема човјека се разоткрива у својој вишедимензијалности. Уочавајући овако сложен и истанчан пишчев приступ теми човјека, епископ Атанасије (Јевтић) у својој књизи посвећеној Достојевском истиче да димензија човјека јесте, с једне стране - личност, али са друге и заједница, иако би се на први поглед чинило да ове двије ствари једна другу искључују (еп. Атанасије 2020: 31). Овоме се може додати и још једна димензија - човјек као саборна личност, свечовјек (мит. Амфилохије 2012: 454). У том контексту се открива релациони однос човјека - онај који захваљујући свом повезивању излази из себе и креће ка другоме, отвара се за другог и друге и надвладавајући свој егоизам, уједињује се и гради саборну личност, то

${ }^{1}$ Достојевски ће касније још једном писати о односу Христа и истине у роману Зли дуси када се Шатов обраћа Ставрогину ријечима: „Да ли сте ми ви оно говорили (...) да ако би вам се математички доказало да је истина ван Христа, да бисте прије жељели да останете са Христом, него са истином“ (Достоевский 1974: 198). 
јесте свечовјека. Човјек - остварена личност као аутентична човјечност се код Достојевског открива истовремено и као слобода и као љубав. Остварена личност је и слободна и слободно воли и твори дјела љубави. Напомињемо, да у дјелима Достојевског љубав можемо пронаћи и у оном облику који постоји у хришћанском Предању. Ријеч је о њеном созерцавању и делању (дјелатна љубав) код Иринеја Лионског (Ириней Лионский 2008: 294) или Максима Исповједника (Максим Исповедник 1993: 98). За њих љубав није осјећање или емотивно стање, већ много важније: једина могућа веза између Бога и човјека као и међу људима, она која повезује, обједињава и уједињује, а да се при томе не угрожава други, његова личност и слобода. То једино бива могуће ако се Бог открива као Љубав (1 Jн 4, 16) као Слово које Оваплоћењем прима људску природу и исцјељује је. Отуд у тенатропологији мјера свега постојећег није ни Бог ни човјек, већ Богочовјек у коме је слободно и несливено присутан и Бог и човјек са цјелокупном творевином.

Велики инквизитор замјера Христу зато што вјерује у слободног човјека, а људи су насупрот томе - створени неслободни. ${ }^{2}$ Такав човјек, дакле, човјек као личност је непотребан свима онима који желе да уређују свијет по својој вољи. Мисао која се открива из дијалога Великог инквизитора и Христа јесте да они који желе да уређују свијет, уопште не поступају по својој вољи, већ по вољи страшног духа из пустиње, кушача, кнеза овога свијета. Занимљива је чињеница да човјека у кога вјерује Христос, описује управо Велики инквизитор: то је човјек чије се срце слободно одазива љубављу на слободну љубав Христову. Човјек потребан Христу, открива Достојевски у роману Браћа Карамазови, јесте човјек у кога вјерује Христос, човјек који може да се уподоби Христу као унутрашњи Христос. И такав лик се у последњем роману Достојевског разоткрива кроз старца Зосиму. То је пуни и савршени лик у човјеку - богочовјечански Лик Христов. Свечовјечна богочовјечност човјека откривена кроз круну стваралаштва Достојевског и јесте једна од црта пишчеве теантропологије.

Међутим, човјек је створен као слободно биће, због чега може да крене и сасвим супротним путем, а то је пут онечовјечења. Епископ Атанасије у свим сегментима људског дјеловања наглашава да постоји опасност од статичности, окамењивања, претварања у систем који се доживљава као окамењена истина зато што у људској природи има склоности ка идолатрији. Тако, на примјер, вјера у човјека (хуманистичка) претвара се у идолопоклонство јер се вјерује, заправо, у силе, стихије и системе који обезличавају човјека, лишавају га лица, индивидуалних црта, због чега се изводи закључак да га у великој мјери онечовјечују. Међутим, иде се и даље од тога: може постојати и стање у коме се чак и Бог може претворити у систем. То је случај са Великим инквизитором јер он својом мишљу, умом који у срцу не пребива, ствара од Бога систем. И увијек када је угрожена слобода човјекова у позадини се може открити систем. Једино је „живи живот“ оно што је у стању да надвлада сваки систем, да про-

\footnotetext{
${ }^{2} \mathrm{O}$ томе у датом контексту пише и Максим Исповједник када појашњава у каквог човјека вјерује Бог по Апостолу Павлу (1 Кор 8, 3): у онога који бивајући слободан, слободно воли (Максим Исповедник 1993: 266).
} 
расте кроз окошталост система. Човјекова жеља да се побиједи такав систем понекад носи са собом могућност да се живот доживи као трагичан, то јесте, да се живот прихвата као пакао на земљи. Гесло човјека из подземља је: пакао то сам ја. Разлоге због којих се долази у овакво стање епископ Атанасије види у недостатку љубави. Без љубави човјек се затвара у мало „ја“, у свој егоизам, и осјећа да га свако други угрожава. За њега је околина, друштво - „сви други“ који стоје наспрам њега, који пријете да угрозе његову слободу поништавајући га као личност. На питање фарисеја шта је највећа Божија заповијест, Христос одговара да је ријеч о љубави: љубави према Богу, а онда и свом ближњем, то јесте, сваком другом човјеку (Мт 22, 37-39). Дух јеванђеља не види љубав као тјелесни нагон или емотивно стање, већ као дјелатност („дјелатна љубав“ коју проповиједа старац Зосима), као подвиг, то јесте - као жртву. Жртвовање свог егоизма и јесте излазак из себе, надвладавање себе, давање себе и Богу и ближњем. Излазак из себе је истовремено и откривање интелигибилног „Ја“. Жртвена љубав у ономе за кога се човјек жртвује открива боголикост. Преко овог мотива митрополит Амфилохије и епископ Атанасије у дјелима Достојевског сагледавају богочовјечански карактер и основу људског бића, а то је човјек и као личност и као заједница. Тентропологија и претпоставља „доживљај, осећај, веру у Бога и човека“ (еп. Атанасије 2020: 119). Под тим условима настаје заједница: када се у себи и у другоме открива, истински човјек - жива слика Живог Бога.

Јустин Поповић је у Достојевском препознао „словенског апостола Лика Христовог“ (Поповић 1940). И тај Лик је и личност и заједница уједно. Оваплоћени Логос, божанска природа која се облачи у тијело, Бог који постаје Човјек како би га жртвеном, крсном љубављу спасао, а не поништио. Божанска природа узвисује човјекову природу до боголикости. Сусрет пролазног лика везаног за земљу и све што је осуђено на нестанак (јер ће бити по Откривењу ново небо и нова земља), прецизније: препображај старе природе, сусреће се са вјечним, непролазним, Божанским Ликом. Ове сусрете у дјелима Достојевског истичу и митрополит Амфилохије и епископ Атанасије, препознајући их наговијештене, на примјер, у сјећањима старца Зосиме на читање старозавјетне приче о Јову, али своје пуно остварење сусрет има у Христу. Ријеч је о теантропологији, вјери у Бога и човјека.

Епископ Атанасије наводи да је следећа истина била позната захваљујући Светом Теофилу Антиохијском још у раном хришћанству, у периоду другог вијека после Христа: прво би требало потражити „у себи истинског човека“, да би се на тај начин дошло до Бога (еп. Атанасије 2020: 120). Исти тај пут, по његовом мишљењу, пролази и сам Достојевски. Прави пут је пут Христов у спајању људске и божанске природе, преображењу те људске природе и њеним васкрсавањем путем Христовог Васкрсења из мртвих. У овоме се открива „тајна“" и човјека о којој пише Достојевски, али и шире - тајна читаве творевине и њеног Творца (еп. Атанасије 2020: 171).

Митрополит Амфилохије истиче да је чежња и туга за свјетлошћу Христовог лика наглашено присутна код оних јунака који инсистирајући искључиво на људској природи остају слијепи за Христов Лик и божански лик у човјеку. То су јунаци за које је такође човјек прелазно биће али не ка Богочовјеку, већ ка Човјекобогу. Јунаци попут Кирилова, Ставрогина, Ивана Карамазова афирмишу 
„пуког човјека“ и долазе до анархизма, нихилизма, и таквог погледа на свијет који почиње са онечовјечењем човјека, афирмацијом човјека-бога, а завршава се са проглашењем човјека-звијери. Па ипак, у њима митрополит открива апофатичку жеђ управо за оним шта поричу, од чега бјеже. И у сваком лику Достојевског гдје се и не говори директно о Христу, „али гдје се пројављује жеђ за слободом, за истином и светошћу, добротом и љубављу“, открива се стремљење ка Христовом Лику (мит. Амфилохије 2012: 453), као нетварној, нествореној и незалазећој свјетлости која чини топлину бића. Одсуство те топлине и јесте пакао као граница између бића и небића - „невидјелица“, „мртвобитије“ (мит. Амфилохије 2012: 455). Код Достојевског природни развој надчовјека прати његово онечовјечивање, то јесте, човјек се превазилази тако што настаје општи човјек у коме се укида личносно начело, а тиме и слобода. Насупрот њему, код Достојевског у роману Браћа Карамазови стоји човјек који своје пуно остварење проналази у заједници (као примјер може послужити догађај стварања заједнице на Иљушином гробу која се заснива на љубави према њему) у осјећању повезаности са читавом творевином (поглед на свијет Маркела и старца Зосиме) и човјек који се спасава као заједница (басна о главици лука).

Заједница у романима Достојевског не представља однос његових јунака (од човјека из подземља па све до Великог инквизитора) према сагледавању проблема човјека у социјалној равни (човјек - друштво у смислу социјума), већ је ријеч о онтолошкој, егзистенцијалној равни (однос личност - заједница). Личност и заједница представљају код Достојевског заједницу Личности, а та заједница има коријене у Ипостаси Христа Богочовјека (теантропологија) и даље, у Светој Тројици. Та заједница чини да је свако од Свете Тројице првенствено Личност.

Онтолошка слика по којој је човјек створен (по лику и подобију, да својом слободном вољом и сарадњом са божанском благодаћу постане Бог) на овај начин чини заједницу, или како каже Свети Василије Велики да је човјек „од Бога створено биће које је добило заповест да постане Бог“ (Григорий Богослов 2000: 730-795; Василий Великий 1891). У Сабраним дјелима Владимира Соловјова постоји свједочанство да је Фјодор Достојевски у разговору, који се одвијао током пута за манастир Оптину 1878. године, нагласио да је централна идеја романа Браћа Карамазови „Црква као позитивни друштвени идеал“ (Соловьев 1912: 197). Соловјов истиче да је Достојевски овом приликом под друштвеним идеалом подразумијевао духовно братство које би било у потпуности супротно друштвеним односима успостављеним у роману Зли дуси. Црква се у православној хришћанској философији схвата као Сабор (саборност), као богочовјечанско сабрање (веза и повезаност, уједињеност) Бога и људи и цјелокупне Божије творевине. Такво виђење Цркве и постоји у Браћи Карамазовима у поглављу Кана Галилејска.

На који начин почиње пут обожења, теозиса? Тако што личност ступа на Христов пут активне, дјелатне љубави која јесте Голгота, пут жртвовања за заједницу. Та жртва мора бити у слободи и љубави остварена, јер су „слобода и љубав бићетворни елементи човјека“ (еп. Атанасије 2020: 32). Једина могућа заједница не укида личност јер се човјек спасава унутар заједнице, прецизније 
речено - као заједница, а таква заједница и чини Цркву. Зато што је Црква заједница Личности. Током цијелог романа Браћа Карамазови препознаје се идеја да се човјек не може спасити самостално, већ једино у оквиру заједнице, јер „наше је биће заједничарско“ (еп. Атанасије 2020: 31). У том погледу за Достојевског је нарочито сликовито већ помињано поглавље Кана Галилејска и басна о главици лука. Ријеч је о својеврсној метафори спасења и након смрти ако се човјек не огради и изолује у своју себичност. У есхатолошкој равни спасење се открива као заједница, Царство Небеско. Када митрополит Амфилохије тумачи мото романа Браћа Карамазови, он то чини наглашавајући управо овај аспекат: „То умирање човјекове самости, његовог ега, његовог самољубља, једини је начин за рашчињавање себе самољубивога и давање себе самога цјеловито давање другима, а наметање себе и своје истине, власти другима“" (мит. Амфилохије 2012: 458). Карактеристичан представник онога који намеће своју власт другима, онај који представља извитоперен дух цркве која постаје идолатријска и која од Бога ствара систем јесте - Велики инквизитор. Он укида слободу узимајући чудо, тајну и ауторитет у своју надлежност како би наметнуо власт друштву, социјуму. Иако проглашава да човјечанство води путем спасења, он му одузима слободу (у чему митрополит види паганску, римску и инквизиторску идеју), намећући му своју власт и свој избор оних искушења која су у јеванђељима описана као кушања ђавола у пустињи $($ Мт 4, 1).

Сагледавајући религиозну димензију Достојевског, митрополит запажа да је битна карактеристика његове вјере екстатична љубав према Христу. Оно што је многе проучаваоце Достојевског збуњивало на први поглед јесте изјава да и када би којим случајем могло да се догоди да истина буде ван Христа, он би ипак више волио да остане са Христом (Достоевский 1985: 176). Христос је тај који се у Новом Завјету открива као, како истиче митрополит Амфилохије, „Онај Који постаје пшенично зрно које се рашчињује и које изнутра даје нови живот“ (митр. Амфилохије 2012: 458). Ово жртвовање себе јесте христолики начин постојања и он, насупрот духу небића кога прихвата Велики инквизитор, једини омогућује дух Богочовјечанства. Као што Достојевски још у младости упознаје дух присилног заједничког живота, друштва без слободе и описује га у Записима из мртвог дома, тако у зрелим годинама описује другачији вид друштва без слободе у Поеми о Великом инквизитору. Једини начин надвладавања оваквог друштва је жива Црква Христова као заједница живих, заједница слободних личности, Црква као свечовечанско саборно Тијело Христово.

Антропоцентрични карактер најзначајнијих дјела Достојевског оба аутора откривају као Христоцентрични. Христос као оваплоћена Ријеч постаје Човјек и тим чином спасава човјека. Истовремено Христос оваплоћењем улази у свијет, у људску историју и даје јој пуни смисао. Христос не само као Бог и не само као човјек, а још мање као свијет постаје мјера свих ствари јер је у Њему несливено присутан и Бог и човјек са тварним свијетом. На тај начин оба аутора у животу и стваралаштву Достојевског као централну тему откривају истинску философију - теантропологију која чини посебним његово дјело и даје му нову димензију. 


\section{Цитирана литература}

Берђајев, Николај: „Достојевски о човеку“. Дело, 27/11-12, 1981: 234-242.

[Berđajev, Nikolaj: „Dostojevski o čoveku“. Delo, 27/11-12, 1981: 234-242]

Василий Великий. Беседы на Шестоднев. Беседа 9 и 10. Творения иже во святых отца нашего Василия Великаго, Архиепископа Кесарии Каппадокийския. Ч.1. Москва, 1891; Беседа 10 по «Журналу Московской Патриархии» 1, 1972. < https:// azbyka.ru/otechnik/Vasilij_Velikij/besedy_na_shestodnev/\#0_9> 13.02.2021. < https://azbyka.ru/otechnik/Vasilij_Velikij/besedy_na_shestodnev/\#0_10>13.02.2021.

[Vasiliı̌ Velikiı̌. Besedy na Shestodnev. Beseda 9 i 10. Tvoreniiä izhe vo sviatykh ottsa nashego Vasiliiā Velikago, Arkhiepiskopa Kesarii Kappadokiı̌skiiā. Ch.1. Moskva, 1891; Beseda 10 po "Zhurnalu Moskovskoř

Patriarkhii” 1, 1972. < https://azbyka.ru/otechnik/Vasilij_Velikij/besedy_na_ shestodnev/\#0_9> 13.02.2021. <https://azbyka.ru/otechnik/Vasilij_Velikij/besedy_ na_shestodnev/\#0_10>13.02.2021]

Григорий Богослов. Собрание творений в 2 тт. Т. 1. Минск: Харвест, Москва: Аст, 2000.

[Grigoriı̌ Bogoslov. Sobranie tvoreniǐ v 2 tt. T. 1. Minsk: Xarvest,Moskva: Ast, 2000]

Достоевский, Федор М. Полное соб. соч. в 30-ти томах. Т. 10. Ленинград: Наука, 1974.

[Dostoevskiı̆, Fedor M. Polnoe sob. soch. v 30-ti tomakh. T. 10. Leningrad: Nauka, 1974]

Достоевский, Федор М. Полное соб. соч. в 30-ти томах. Т. 28/1. Ленинград: Наука, 1985.

[Dostoevskiĭ, Fedor M. Polnoe sob. soch. v 30-ti tomakh. T. 28/1. Leningrad: Nauka, 1985]

Захаров, Владимир Н. «Ответ по существу». [В:] В.Н. Захаров (ред.) Евангельский текст в русской литературе XVIII-XX веков. Петрозаводск: ПетрГУ, 2005, 5-16.

[Zakharov, Vladimir N. «Otvet po sushchestvu». [V:] V.N. Zakharov (red.) Evangel'skiü tekst v russkoĭ literature KhVIII-KhKh vekov. Petrozavodsk: PetrGU, 2005, 5-16.]

Ириней Лионский. Против ересей. Санкт-Петербург: Изд-тво Олега Абышко, 2008. [Irineĭ Lionskiı̌. Protiv ereseǐ. Sankt-Peterburg: Izd-tvo Olega Abyshko, 2008]

Јевтић, Атанасије. Достојевски. Врњци: Интерклима-графика, Требиње: Манастир Тврдош, Алхамбра:

Севастијан прес, 2020.

[Jevtić, Atanasije. Dostojevski. Vrnjci: Interklima-grafika, Trebinje: Manastir Tvrdoš, Alhambra: Sevastijan pres, 2020]

Максим Исповедник. Творения. Богословские и аскетические трактаты. Т. 1. Москва: МАРТИС, 1993.

[Maksim Ispovednik. Tvoreniiā. Bogoslovskie i asketicheskie traktaty. T. 1. Moskva: MARTIS, 1993]

Поповић, Јустин: „Достојевски као пророк и апостол православног реализма“. Богословље, 15/2, 1940:

91-102. <https://www.rastko.rs/rastko-ru/delo/12932> 13.08.2008.

[Popović, Justin: „Dostojevski kao prorok i apostol pravoslavnog realizma“. Bogoslovlje, 15/2, 1940: 91-102. <https://www.rastko.rs/rastko-ru/delo/12932> 13.08.2008]

Радовић, Амфилохије: „Пневматолошки метод“. [У:] Милошевић, Никола и Радовић, Амфилохије. Дијалог о Достојевском - религијска мисао и Достојевски. 
Савременик 29/58/11, 1983: 403-424.

[Radović, Amfilohije: „Pnevmatološki metod“. [U:] Milošević, Nikola i Radović, Amfilohije. Dijalog o Dostojevskom - religijska misao i Dostojevski. Savremenik, 29/58/11, 1983: 403-424]

Радовић, Амфилохије. Изабрана дјела Архиепископа Цетињског и Митрополита Црногорско-приморског Амфилохија (Радовића). Т. 8. Богословска слова. Студије и есеји, предавања и записи. Књига прва. Цетиње: Светигора, 2012.

[Radović, Amfilohije. Izabrana djela Arhiepiskopa Cetinjskog i Mitropolita Crnogorskoprimorskog Amfilohija (Radovića). T. 8. Bogoslovska slova. Studije i eseji, predavanja i zapisi. Knjiga prva. Cetinje: Svetigora, 2012]

Соловьевъ, Владимір С. Собраніе сочиненій. Т.3. С.-Петербургъ: Просвъщение 1912. [Solov'ev", Vladimir S. Sobranie sochineniǐ. T.3. S.-Peterburg": Prosvbshchenie 1912]

\title{
Неда Андрич
}

\section{МИТРОПОЛИТ АМФИЛОХИЙ (РАДОВИЧ) И ЕПИСКОП АФАНАСИЙ (ЕВТИЧ): ТЕАНТРОПОЛОГИЯ ДОСТОЕВСКОГО}

\begin{abstract}
Резюме
Настоящая работа посвящена рецепции творчества Федора Михайловича Достоевского в критической литературе митрополита Черногорско-приморского Амфилохия (Радовича) и епископа Афанасия (Евтича) через призму теантропологии. «Тайна человека» и «человек как тайна» становятся предметом исследования митрополита Амфилохия и епископа Афанасия. У обоих авторов подчеркнута мысль, что ключевая проблема в творчестве Достоевского человек, а именно «очеловечивание человека», и что писатель всегда исходит из своего личного опыта при размышлении о различных измерениях человека. Чтобы вообще начать путь очеловечивания, необходимо обнаружить истинного человека, а именно, верить не только в Бога, но и в человека. Мерой же человека может быть только Богочеловек - Личность, которая соединяет две природы - человеческую и божественную. Тогда раскрывается истинная мера человека - Христос. В этом содержится теантропология Достоевского: не только человеку нужен Бог, но и Богу нужен человек для спасения своего творения. Вот почему в домостроительстве спасения особую роль играет боговоплощение Логоса - искупление греха возможно только через Крестную смерть Сына Божия и Сына Человеческого. Митрополит Амфилохий узнает экстатическую любовь ко Христу в жизненном пути Федора Михайловича Достоевского, к тому же епископ Афанасий - жажду по Христу и стремление к Нему.

Ключевые слова: Федор Достоевский, теантропология, человек, Богочеловек, Христос, митрополит Амфилохий (Радович), епископ Афанасий (Евтич).
\end{abstract}

